\title{
PENERAPAN CONTEXTUAL TEACHING LEARNING PADA MATERI FIKIH DAN SEJARAH KEBUDAYAN ISLAM JENJANG MADRASAH ALIYAH
}

\author{
Budi Mulia \\ Universitas Pamulang \\ E-mail: dosen01549@unpam.ac.id
}

\begin{abstract}
Abstrak
Tulisan ini bertujuan untuk mengkaji penerapan metode pembelajaran CTL pada mata pelajaran Fikih dan Sejarah Kebudayaan Islam di Madrasah Aliyah Negeri Insan Cendekia Serpong Kota Tangerang Selatan. Metode penelitian kualitatif digunakan untuk mengkaji data dan informasi terkait tema tulisan. Hasil penelitian menunjukkan bahwa implementasi pembelajaran konstektual pada mata pelajaran agama Islam dengan cara mengkonstruksikan pengetahuan siswa terhadap materi yang akan disampaikan. Siswa dapat menemukan informasi baru melalui curah pendapat dan mencari tambahan materi yang sedang dipelajari melalui internet atau media cetak.
\end{abstract}

Kata Kunci: CTL, Fikih, Sejarah Kebudayaan Islam, metode pembelajaran

\section{Pendahuluan}

Peranan guru dalam proses pembelajaran dapat menentukan kesuksesan siswa dalam menerima ilmu pengetahuan dan menambah keterampilan melalui pengembangan kompetensi yang dimiliki oleh siswa yang diarahkan dan dibimbing oleh guru untuk mencapai tujuan pendidikan.

Format pendidikan yang tidak seimbang antara materi dengan metode pembelajaran dapat menimbulkan beberapa permasalahan yang akan merusak sistem dan tujuan pendidikan. Efek dari kebutuhan yang terabaikan serta pemilihan metode yang tidak tepat dapat menimbulkan fenomena empiris yang menunjukan bahwa saat ini terdapat banyak kasus kenakalan pelajar. Isu perkelahian pelajar, tindak kekerasan telah mewarnai halaman surat kabar, majalah, dan media massa lainnya.

Pola pembelajaran konvensional ditandai dengan pengalaman siswa terbatas hanya sekedar mendengarkan materi dari guru. Siswa diberi kesempatan mengeksplorasi namun selalu bermuara pada instruksi dari guru yang bersifat teacher centris. Pendekatan student centris merupakan salah satu metode yang diusung oleh CTL (Contextual Teaching and Learning) yaitu metode pembelajaran CTL.

Metode yang kurang baik dapat berdampak kepada pemahaman peserta didik terhadap materi yang dipelajari. Pemilihan metode yang tepat dapat mengefektifkan pembelajaran sehingga siswa memiliki pengetahuan dan memaknai pengetahuan itu 
berdasarkan konteks yang dilihat dan dialaminya. Pemilihan metode yang sesuai dengan materi pelajaran yang disajikan dapat mengoptimalkan proses pembelajaran sehingga keberhasilan pembelajaran dapat tercapai.

Selama ini para siswa menganggap mata pelajaran pendidikan agama Islam termasuk pelajaran yang kurang menarik. Hal ini diungkapkan oleh Fuad Jabali bahwa ketidaktertarikan siswa dalam mempelajari pendidikan agama Islam menyebabkan sebagian siswa bosan dalam belajar pendidikan agama Islam, sehingga siswa kurang berminat terhadap pelajaran tersebut dan berimplikasi pada kualitas yang diperoleh kurang memuaskan sehingga pemahaman terhadap pendidikan agama Islam belum dirasakan maknanya. ${ }^{1}$

Dalam beberapa hal pendidikan nasional secara umum dan pendidikan agama secara khusus dinilai "gagal" dalam menanamkan akhlak terhadap peserta didik, sehingga memunculkan gagasan tentang adanya pendidikan budi pekerti untuk diajarkan disetiap jenjang pendidikan dasar sampai perguruan tinggi. Banyak peserta didik sering dinilai tidak memiliki kesantunan dan penghormatan serta penghargaan kepada orang lain baik di sekolah, rumah dan masyarakat melainkan juga sering terlibat pada tindakan-tindakan kriminal atau kekerasan secara massal seperti tawuran pelajar.

Gejala-gejala tersebut dapat ditemukan pada anak yang sedang menginjak usia remaja yang secara psikologis usia mereka sangat rentan terhadap pengaruh dari luar dirinya yang berakibat pada dorongan emosi yang tidak stabil pula. Oleh karena itu sebagian orang menganggap bahwa kemerosotan akhlak peserta didik disebabkan gagalnya pendidikan agama di sekolah karena mengalami banyak kelemahankelemahan. $^{2}$

\footnotetext{
${ }^{1}$ Fuad Jabali, International Workshop: Teaching Methodology and Capacity Building For Teachers of Islamic Subject in High Schools in High Propinces, PPIM Syarif Hidayatullah Tanggal 12 Agustus 2012

${ }^{2}$ Azyumardi Azra menilai bahwa dalam batas tertentu pendidikan agama memiliki kelemahankelemahan tertentu, sejak dari jumlah jam minim, meteri agama yang terlalu banyak teoritis, sampai kepada pendekatan pendidikan agama yang cenderung bertumpu pada aspek kognisi daripada aspek afeksi dan psikomotorik peserta didik. Lebih jauh Djohar dan Navis menyatakan bahwa krisis mentalis dan moral peserta didik, terdapat beberapa masalah pokok yang turut menjadi akar krisis mentalis dan moral di lingkungan pendidikan nasional antara lain: pertama, arah pendidikan telah kehilangan obyektifitasnya, kedua, proses pendewasaan diri tidak berlangsung dengan baik di lingkungan sekolah, ketiga, proses pendidikan di sekolah sangat membelenggu peserta didik bahkan para guru, keempat, beban kurikulum semakin berat dan lebih parahnya lagi hampir sepenuhnya diorientasikan pada pengembangan ranah kognitif belaka, kelima, kalaupun ada materi yang dapat menumbuhkan rasa afeksi seperti mata pelajaran agama, umumnya disampaikan dalam bentuk verbalisme, keenam, pada saat yang bersamaaan para peserta didik dihadapkan kepada nilai-nilai yang sering bertentangan. Lihat: Azyumardi
} 
Guru agama Islam identik dengan tugas yang mengedepankan moral, perilaku dan mengontrol aktivitas ibadah siswa-siswinya. Ketika terdapat permasalahan yang berhubungan dengan aspek moral dan perilaku siswa-siswi guru agama Islam menjadi sorotan utama, padahal tugas yang paling dominan untuk mendidik perilaku siswa-siswi merupakan tanggung jawab orangtua karena mereka lebih bebas mengontrol perilaku anaknya di luar jam sekolah. Pembelajaran pendidikan agama Islam masih cenderung berfokus kepada angka nilai bagus yang didapatkan peserta didik ketimbang bagaimana menanamkan nilai-nilai ajaran agama ke dalam sanubari mereka.

Metode pendidikan agama Islam di sekolah masih berupa hapalan-hapalan dan ceramah sehingga siswa hanya dituntut kognitifnya saja sedangkan nilai-nilai agama itu tidak dapat ditransfer dengan metode seperti itu saja, akan tetapi alangkah baiknya bila pengamalan yang bersifat afektif dan psikomotorik berjalan beriringan sehingga tercipta satu pemahaman dan tindakan yang komprehensif. Proses pendidikan untuk mencapai dimensi-dimensi nilai afektif yang bersifat intrinsik dari tujuan pendidikan seringkali terabaikan dan hanya menjadi efek penyerta dari upaya pendidikan.

Dalam menggapai keberhasilan dari proses pembelajaran tentunya dapat merujuk kepada yang telah dilakukan oleh para nabi dan rasul, selain itu diperlukan pendekatan CTL dalam pembelajaran, hal ini berdasarkan adanya kenyataan bahwa sebagian besar siswa tidak mampu menghubungkan antara apa yang mereka pelajari dengan bagaimana pemanfaatannya dalam kehidupan nyata.

Pengaruh untuk menjadikan proses pembelajaran CTL melalui salah satunya mengelola kelas, atau memberikan kunci untuk teka-teki dari setiap aktivitas yang terjadi di dalam kelas. Setiap siswa dapat dikondisikan dengan baik walaupun mereka yang mengajar dengan penekanan untuk mengadopsi. Guru yang suka dan menghormati siswa cenderung memiliki lebih sedikit masalah disiplin. Dengan kata lain madrasah merupakan pendidikan yang dapat membangun disiplin sebagai dari salah satu tujuan untuk menjadikan pembelajaran yang bermakna dalam setiap aktivitas di dalam kelas.

Salah satu sekolah yang disinyalir menerapkan konsep pembelajaran CTL dalam kurikulum adalah Madrasah Aliyah Negeri Insan Cendekia Serpong dengan alasan sekolah ini merupakan sekolah unggulan yang bertaraf nasional yang memiliki prestasi gemilang dan menunjukan perilaku akhlak mulia dalam kehidupan sehari-hari sebagai

Azra, Pendidikan Islam, Tradisi dan modernisasi Menuju Milennium baru, (Jakarta : Logos Wacana Ilmu, 1999) 
barometer terciptanya keseimbangan iklim keimanan, akhlak dan pengetahuan. Salah satu best practice yang dimiliki oleh MAN Insan Cendekia Serpong adalah penanaman saling hormat menghormati kepada sesama, hal ini dibiasakan ketika bertemu selalu mengucapkan salam. Untuk mencapai tujuan dalam pembentukan karakter, diperlukan format khusus dalam memberikan solusi terhadap metode pembelajaran dewasa ini yaitu metode pembelajaran CTL.

Beberapa penelitian terdahulu yang relevan, di antaranya Zakiyah Daradjat dalam Metodologi Pengajaran Agama Islam, dalam penelitiannya memaparkan tentang beberapa metode yang digunakan dalam pendidikan agama Islam ditinjau melalui metode yang berasal dari alqur'an dan dipadukan dengan metode pembelajaran yang berkembang serta didukung dengan beberapa contoh.

Wina Sanjaya dalam Pembelajaran Dalam Implementasi Kurikulum Berbasis Kompetensi, dalam penelitiannya berisi tentang tinjauan teoritis dan praktis mengenai bagaimana seharusnya guru melaksanakan pembelajaran dalam kerangka implementasi KBK. Pembahasannya meliputi hal-hal yang berkaitan dengan metode kurikulum, desain KBK melalui proses belajar, strategi pembelajaran, dan metode pembelajaran; peningkatan kemampuan berfikir, kompetensi profesional guru dalam kerangka KBK dan evaluasi pembelajaran dalam KBK.

Elaine B. Johnson dalam bukunya Contextual Teaching \& Learning: Menjadikan Kegiatan Belajar-Mengajar Mengasyikkan dan Bermakna, pada buku ini diulas berkenaan dengan metode dan sistem belajar yang didasarkan pada filosofi bahwa seorang pembelajar akan mau dan mampu menyerap materi pelajaran. Peserta didik dapat menangkap makna dari pelajaran tersebut. Dalam buku ini juga membedah dasardasar filosofi tersebut dari sudut pandang ilmu psikologi dan contoh-contoh yang dikembangkan dalam metode pembelajaran CTL serta apresiasi dari seluruh kalangan karena ternyata metode Contextual Teaching and Learning sudah berhasil diterapkan.

Tesis Jamaludin, dalam tesis tersebut digambarkan skema manajemen berbasis sekolah, inti pada penelitian itu berkenaan dengan manajemen berbasis madrasah seperti penyusunan kurikulum dan sumber belajar sebagai ciri khas dalam manajemen berbasis sekolah. ${ }^{3}$ Tesis ini meneliti metode pembelajaran CTL yang telah diteliti sebelumnya oleh Elaine B. Johnson. Landasan dua teori ini sebagai pijakan dalam menciptakan

\footnotetext{
${ }^{3}$ Jamaludin, Manajemen Berbasis Sekolah di Indonesia, (Jakarta: UIN Syahid Jakarta, 2007)
} 
pembelajaran yang bermakna secara khusus menjelaskan mengenai metode pembelajaran CTL, implementasi serta dampak yang ditimbulkannya. Adapun proses metode pembelajaran CTL yang diimplementasikan adalah metode dalam dalam pelajaran Al-Qur'an Hadis, Fiqih, Sejarah Kebudayaan Islam, Akidah Akhlak dan Bahasa Arab melalui pendekatan pembelajaran CTL.

Berdasarkan latar belakang di atas, tulisan ini bertujuan untuk mengkaji penerapan metode pembelajaran CTL pada mata pelajaran Fikih dan Sejarah Kebudayaan Islam di Madrasah Aliyah Negeri Insan Cendekia Serpong Kota Tangerang Selatan.

\section{Metode}

Ada beberapa teknik dalam mengumpulkan data terhadap objek yang akan diteliti yaitu; Observasi: Observasi dilakukan secara langsung (direct observation) yang dilakukan dengan cara door to door ke dalam kelas untuk mengetahui gambaran riil melalui pengamatan langsung dengan memperhatikan situasi dan kondisi serta mencatat hasil pengamatan yang berkaitan dengan proses pembelajaran serta sarana pendukung bagi kelancaran pembelajaran agama Islam di lingkungan MAN Insan Cendekia Serpong Kota Tangerang Selatan. Observasi dilakukan terhadap guru, siswa, sarana prasarana, administrasi dan aktifitas belajar mengajar serta perilaku siswa di luar kelas. Observasi ini dilakukan dalam jangka waktu selama tiga bulan, namun peneliti tidak setiap hari meneliti tergantung pada jadwal masing-masing kelas serta jadwal wawancara terhadap narasumber yang bersangkutan.

Wawancara: Wawancara dilakukan dengan mendatangi berbagai pihak yang dianggap mengetahui permasalahan yang hendak dibahas. Penggalian data melalui wawancara ini dilakukan terhadap kepala sekolah, wakil kepala sekolah bidang kurikulum, humas, tata usaha, para guru dan peserta didik Madrasah Aliyah Negeri Insan Cendekia Serpong. Wawancara yang digunakan adalah wawancara terstruktur yakni wawancara yang disusun terlebih dahulu, namun disesuaikan dengan keadaan dan ciri yang unik dari responden. Pelaksanaaan tanya jawab mengalir seperti dalam percakapan sehari-hari.

Dokumentasi: Dokumentasi dimaksudkan untuk mengambil fakta-fakta yang berupa foto-foto kegiatan yang berlangsung pada sekolah yang dijadikan obyek penelitian. Ada beberapa penghargaan baik tingkat nasional maupun tingkat internasional yang diraih oleh siswa MAN Insan Cendekia Serpong. 


\section{Pembahasan}

\section{Metode Pembelajaran CTL Fikih}

Mata pelajaran Fikih di Madrasah Aliyah adalah salah satu mata pelajaran pendidikan agama Islam yang merupakan peningkatan dari Fikih yang telah dipelajari oleh peserta didik di Madrasah Tsanawiyah/SMP.

Peningkatan tersebut dilakukan dengan cara mempelajari, memperdalam, serta memperkaya kajian Fikih baik yang menyangkut aspek ibadah maupun muamalah, yang dilandasi oleh prinsip-prinsip dan kaidah-kaidah usul Fikih untuk menggali tujuan hikmahnya, sebagai persiapan untuk melanjutkan kepada pendidikan yang lebih tinggi dan untuk hidup bermasyarakat. ${ }^{4}$

Secara substansial, mata pelajaran Fikih memiliki kontribusi dalam memberikan motivasi kepada peserta didik untuk mempraktikkan dan menerapkan hukum Islam dalam kehidupan sehari-hari sebagai perwujudan keserasian, keselarasan, dan keseimbangan hubungan manusia dengan Allah SWT. Dengan diri manusia itu sendiri, sesama manusia, makhluk lainnya ataupun lingkungannya.

Mata pelajaran Fikih di Madrasah Aliyah bertujuan untuk:

1. Mengetahui dan memahami prinsip-prinsip, kaidah-kaidah dan tata cara pelaksanaan hukum Islam baik yang menyangkut aspek ibadah maupun muamalah untuk dijadikan pedoman hidup dalam kehidupan pribadi dan sosial.

2. Melaksanakan dan mengamalkan ketentuan hukum Islam dengan benar dan baik, sebagai perwujudan dari ketaatan dalam menjalankan ajaran agama Islam baik dalam hubungan manusia dengan Allah, dengan diri manusia itu sendiri, sesama makhluk manusia, dan makhluk lainnya maupun hubungan dengan lingkungannya. ${ }^{5}$

Selain itu menurut Muhammad Abdul Qadar Ahmad bahwa tujuan pembelajaran Fikih Ibadah antara lain:

1. Ibadah dapat menguatkan akidah dalam jiwa murid.

2. Ibadah dapat menghubungkan manusia dengan Allah, menambah kepatuhannya kepada Tuhan melalui shalat, puasa, zakat, haji dan Ibadat lainnya.

3. Menumbuhkan rasa sosial dalam interaksi dengan teman-teman sepergaulannya, seperti shalat berjamaah.

4. Membentuk rasa persamaan diantara dewasa dengan anak muda antara orang miskin dengan orang kaya.

\footnotetext{
${ }^{4}$ Peraturan Menteri Agama Nomor 8 Tahun 2008 tentang Standar Kompetensi Lulusan dan Standar Isi Pendidikan agama Islam dan Bahasa Arab di Madrasah, h. 47

${ }^{5}$ Peraturan Menteri Agama Nomor 8 Tahun 2008 tentang Standar Kompetensi Lulusan dan Standar Isi Pendidikan agama Islam dan Bahasa Arab di Madrasah.
} 


\section{Memelihara kebersihan dan kesucian diri. $^{6}$}

Secara istilah, kata Fikih didefinisikan oleh para ulama dengan berbagai definisi yang berbeda-beda. Sebagiannya lebih merupakan ungkapan sepotong-sepotong, tapi ada juga yang memang sudah mencakup semua batasan ilmu Fikih itu sendiri. ${ }^{7}$

Pembelajaran Fiqih pada metode pembelajaran CTL (Contextual Teaching and Learning) merupakan konsep belajar yang membantu guru mengaitkan antara materi yang diajarkan dengan situasi dunia nyata siswa dan mendorong siswa membuat hubungan antara pengetahuan yang dimiliki dengan penerapannya dalam kehidupan mereka sebagai anggota keluarga dan masyarakat.

Dengan konsep itu, hasil pembelajaran diharapkan lebih bermakna bagi siswa. Proses pembelajaran berlangsung alamiah dalam bentuk kegiatan siswa bekerja dan mengalami, bukan mentransfer pengetahuan dari guru kepada siswa. Strategi pembelajaran lebih dipentingkan daripada hasil.

Dalam kelas kontektual, tugas guru adalah membantu siswa mencapai tujuannya. Maksudnya, guru lebih banyak berurusan dengan strategi daripada memberi informasi.

Menurut Firdaus bahwa "metode ini diharapkan agar dunia pendidikan selalu berdealiktika dengan keadaan zaman. Karena jika pendidikan tidak memiliki semangat yang demikian, maka pendidikan justru akan menjadi alat untuk mencabut tradisi masyarakat dari kultur yang selama ini diwarisinya." 8

Menurut Abdul Rahman Saleh bahwa:

Kegiatan pembelajaran CTL dengan harapan untuk memberikan sikap keterbukaan, menimbulkan demokrasi dan toleransi mengingat pembelajaran ini mampu mengembangkan daya kreasi, daya nalar, rasa keingintahuan dan eksperimentasi-eksperimentasi yang dimungkinkan terjadinya penemuan-penemuan baru. ${ }^{9}$

Metode pembelajaran Fikih di kelas X menggunakan metode pembelajaran CTL yang berkaitan dengan meteri tentang riba bank, dan asuransi. ${ }^{10}$

Pada awal pembelajaran guru memberikan penyegaran ingatan melalui apersepsi dengan cara mengulang kembali pelajaran telah dilalui kemudian guru memberikan gambaran yang berkenaan dengan materi pelajaran yang akan disampaikan yaitu tentang riba bank dan asuransi.

\footnotetext{
${ }^{6}$ Muhammad Abdul Qadir Ahmad, Thuruqu Ta'limi Al-Tarbiyah Al-Islamiyah: Metodologi Pengajaran Pendidikan Agama Islam, (Jakarta: Direktorat Jenderal Pembinaan Kelembagaan Agama Islam, 1985), h. 150

${ }^{7}$ http://ar-rovic.blogspot.com/2013/03/pengertian-fiqih.html tanggal 12 Juli 2013

${ }^{8}$ Firdaus M. Yunus, Pendidikan Berbasis Realitas Sosial-Paulo Freire dan YB. Mangunwijaya, (Yogyakarta: Logung Pustaka, 2005), hlm. xii

${ }^{9}$ Abdul Rachman Shaleh, Madrasah Dan Pendidikan Anak Bangsa: Visi, Misi dan Aksi, (Jakarta: PT Raja Grafindo Persada, 2004), h. 226-227

${ }^{10}$ Observasi Kelas X Fikih, tanggal 8 Mei 2013
} 
Upaya seperti itu guru sedang membangun pemahaman mereka sendiri dari pengalaman baru berdasar pada pengetahuan awal dan ini merupakan proses dari pembelajaran bermakna. Setelah pengetahuan baru disampaikan siswa dapat menghubungkan dengan cara mengkonstruksikan pengetahuan menjadi pemahaman bukan menerima pengetahuan.

Setelah materi secara umum selesai diberikan selanjutnya siswa kepada diarahkan untuk menemukan pengertian riba bank dan asuransi secara individual melalui buku paket dan sumber lainnya, kemudian siswa mempelajari sehingga proses pembelajaran berpindah dari pengamatan menjadi pemahaman. Hal tersebut dapat memotivasi siswa agar dalam proses pembelajaran menggunakan keterampilan berpikir kritis.

Siswa kritis dalam berpikir memiliki modal bertanya terhadap beberapa hal yang tidak diketahuinya. Guru memberikan penawaran pertanyaan kepada siswa. Pertanyaan yang dimaksud tidak hanya dijawab oleh guru saja tetapi siswa lainpun diberikan kesempatan untuk menjawab setiap pertanyaan yang diajukan oleh siswa. Kegiatan ini dilakukan untuk mendorong, membimbing dan menilai kemampuan berpikir siswa sehingga antara guru dan siswa saling berbagi informasi melalui komunikasi.

Selanjutnya guru membagi ke dalam beberapa kelompok, kelompok yang pertama mendiskusikan pengertian riba bank dan kelompok lainnya mendiskusikan tentang asuransi. Kelompok masing masing siswa memberikan penjelasan tentang pengertian riba bank dan asuransi. Siswa satu dengan lainnya saling bertukar pengalaman terhadap pengalaman yang terjadi di masyarakat, yang memerlukan adanya bank untuk bertransaksi simpan pinjam demi memenuhi kebutuhan masyarakat.

Saat ini berkembang bank keliling yang sebagian besar terjadi di masyarakat. Seakan-akan bank keliling merupakan salah satu alternatif dalam memenuhi kebutuhan dengan berbagai alasan dan upaya untuk dapat mencukupinya. Dari gambaran tersebut masing-masing siswa dapat menelaah dan memberikan argumentasi dalam membincangkan masalah bank keliling apakah lebih banyak manfaatnya walaupun terdapat riba di dalamnya. Hal ini dapat didiskusikan pada masing-masing kelompok sehingga masing-masing siswa dapat memberikan penilaian positif atau negatif dari sebuah transaksi simpan pinjam bank keliling.

Setiap kelompok memaparkan hasil telaahannya terhadap pengalaman yang berkembang di masyarakat. Kemudian dari kelompok yang dapat memaparkan secara maksimal menjadi prioritas dalam sebuah kegiatan pembelajaran untuk dijadikan model. Pada tahap model proses berfikir, bekerja dan belajar dapat dilakukan atau diimplementasikan oleh siswa itu sendiri.

Langkah selanjutnya siswa diarahkan oleh guru untuk merefleksikan atau merenungkan pembelajaran yang telah disampaikan sehingga siswa dapat memahami makna yang terkandung dalam pembelajaran riba bank dan asuransi. Pembelajaran tersebut dapat diambil intisarinya melalui proses berfikir yang dituangkan dalam catatan, sehingga siswa dapat mengetahui hukum riba dan menjauhi riba berdasarkan pengalaman yang telah dilalui dan didiskusikannya.

Selanjutnya guru dapat memberikan catatan dari proses pembelajaran dari awal sampai dengan akhir untuk dijadikan pedoman penilaian nyata yang telah dilakukan 
oleh siswa berdasarkan hasil pengamatan secara cermat, sehingga penilaian siswa bersifat adil sesuai dengan kompetensi siswa yang dimilikinya.

Pembelajaran CTL siswa dapat mengambarkan keadaan masyarakat yang memerlukan sejumlah uang dalam memenuhi kebutuhannya. Siswa dipacu untuk memperhatikan kondisi lingkungannya.

Agama Islam mencegah praktik-praktik yang mengarah kepada riba, karena di dalamnya terdapat unsur yang akan merugian pihak lain. Namun pada kenyataannya masyarakat membutuhkan sehingga bank keliling menjadi salah satu alternatif untuk memenuhi kebutuhan hidup.

Dampak yang dihasilkan pada metode pembelajaran CTL diantaranya adalah siswa dapat mengemukakan pendapat yang ada dalam pikirannya terkait dengan hukum riba bank dan asuransi. Melatih siswa untuk berbicara dihadapan guru dan teman-temannya untuk mengemukakan pendapatnya. Hal ini merupakan proses keberanian yang dapat dimiliki oleh masing-masing siswa.

Selanjutnya siswa terbiasa untuk dapat memecahkan masalah. Hal ini merupakan sebuah proses yang tidak mudah karena siswa dituntut untuk mengamati dahulu tentang riba bank dan asuransi yang akan dipecahkan dengan merujuk kepada Al-Qur'an dan Hadis.

Siswa dapat melakukan proses pembelajaran lebih sempurna karena siswa mengalami secara langsung tentang riba bank dan asuransi yang berkembang di masyarakat. Siswa menjadi modelnya sendiri sehingga siswa dapat mengoptimalkan kemampuannya dalam menggali informasi dengan cara mengamati secara langsung praktek bank keliling.

Dampak selanjutnya siswa memiliki target untuk menjadi yang terbaik karena guru menilai siswa secara keseluruhan dengan penilaian asli sehingga siswa berupaya penuh dan aktif dalam pembelajaran.

Pengalaman dalam pembelajaran CTL memberikan pembelajaran yang kreatif, siswa tidak hanya diam namun mencari informasi yang dapat menunjang pengetahuannya secara bertahap.

Dampak pembelajaran CTL dapat mempengaruhi kepribadian psikis siswa bahwasannya kebutuhan yang mendesak masyarakat memilih meminjam sejumlah uang ke bank keliling. Sehingga diantara siswa terenyuh dan dapat berhemat karena uang jajan yang selama ini diberikan oleh orang tua seyogyanya dapat dimanfaatkan dengan baik.

\section{A. Metode Pembelajaran CTL Sejarah Kebudayaan Islam}

Sejarah Kebudayaan Islam merupakan salah satu mata pelajaran yang menelaah tentang asal-usul, perkembangan, peranan kebudayaan/peradaban Islam di masa 
lampau, mulai dari dakwah Nabi Muhammad pada periode Makkah dan periode Madinah. ${ }^{11}$

Menurut Louis Gottschalk dalam Abuddin Nata bahwa "sejarah terdiri dari unsur peristiwa atau kejadian (what), waktu (when), tempat (where), pelaku (who), mengapa (why), dan apa (how), yang selanjutnya di singkat menjadi $5 \mathrm{~W} 1 \mathrm{H} .{ }^{, 12}$

Kepemimpinan umat setelah Rasulullah SAW wafat, sampai perkembangan Islam periode klasik (zaman keemasan) pada tahun 650 M-1250 M., abad pertengahan/zaman kemunduran (1250-1800 M), dan masa modern/zaman kebangkitan (1800-sekarang), serta perkembangan Islam di Indonesia dan di dunia. Secara substansial mata pelajaran Sejarah Kebudayaan Islam memiliki kontribusi dalam memberikan motivasi kepada peserta didik untuk mengenal, memahami, menghayati Sejarah Kebudayaan Islam, yang mengandung nilai-nilai kearifan yang dapat digunakan untuk melatih kecerdasan, membentuk sikap, watak, dan kepribadian peserta didik. ${ }^{13}$

Mata pelajaran Sejarah Kebudayaan Islam di Madrasah Aliyah bertujuan agar peserta didik memiliki kemampuan-kemampuan sebagai berikut:

1. Membangun kesadaran peserta didik tentang pentingnya mempelajari landasan ajaran, nilai-nilai dan norma-norma Islam yang telah dibangun oleh Rasulullah SAW dalam rangka mengembangkan kebudayan dan peradaban Islam.

2. Membangun kesadaran peserta didik tentang pentingnya waktu dan tempat yang merupakan sebuah proses dari masa lampau, masa kini, dan masa depan.

3. Melatih daya kritis peserta didik untuk memahami fakta sejarah secara benar dengan didasarkan pada metode ilmiah.

4. Menumbuhkan apresiasi dan penghargaan peserta didik terhadap peninggalan sejarah Islam sebagai bukti peradaban umat Islam di masa lampau.

5. Mengembangkan kemampuan peserta didik dalam mengambil ibrah dari peristiwa-peristiwa bersejarah (Islam), meneladani tokoh-tokoh berprestasi, dan mengaitkannya dengan fenomena sosial, budaya, politik, ekonomi, iptek dan seni serta lainnya untuk mengembangkan kebudayaan dan peradaban Islam. $^{14}$

Menurut Muhammad Abdul Qadir Ahmad bahwa tujuan mengajar sejarah yaitu:

Pertama, untuk menyerap unsur-unsur keutamaan dari padanya agar mereka dengan senang hati mengikuti tingkah laku para nabi dan orang-orang saleh dalam kehidupan sehari-hari maupun dalam menghadapi kesulitan-kesulitan hidup mereka. Kedua, sejarah merupakan contoh teladan baik bagi umat Islam yang

\footnotetext{
${ }^{11}$ Peraturan Menteri Agama Nomor 8 Tahun 2008 tentang Standar Kompetensi Lulusan dan Standar Isi Pendidikan agama Islam dan Bahasa Arab di Madrasah.

${ }^{12}$ Abuddin Nata, Studi Islam Komprehensif, (Jakarta: Kencana, 2011),h. 337

${ }^{13}$ Abuddin Nata, Studi Islam Komprehensif, (Jakarta: Kencana, 2011),h. 337

${ }^{14}$ Peraturan Menteri Agama Nomor 8 Tahun 2008 tentang Standar Kompetensi Lulusan dan Standar Isi Pendidikan agama Islam dan Bahasa Arab di Madrasah.
} 
meyakinkannya dan merupakan sumber syari'at yang besar. Ketiga, sejarah dapat mengembangkan iman, mensucikan moral, membangkitkan patriotisme dan mendorong untuk berpegang pada kebenaran serta setia kepadanya. Keempat, sejarah akan memberikan contoh teladan yang sempurna kepada pembinaan tingkah laku manusia yang ideal dalam kehidupan pribadi dan sosial anak-anak dan mendorong mereka untuk mengikuti teladan yang diterima sebagai realita hidup dari sejarah Rasul, bertingkah laku seperti akhlak Rasul. ${ }^{15}$

Kebudayaan Islam menurut Muhammad Abdul Qadir Ahmad adalah "hasil fikir dan karya manusia yang didasarkan kepada pemahaman Islam yang beragam. Artinya kebudayaan Islam lahir dari pemahaman ajaran yang mengatur kehidupan masyarakat yang menganut agama Islam sejak datangnya wahyu." 16

Menurut Abdul Qadir Ahmad bahwa:

Tujuan mempelajari kebudayaan Islam sebagai berikut:

1. memperbaiki pemikiran terhadap Islam dan memelihara generasi muda dari bahaya yang membawa kelemahan dan kehancuran yang menimpa mereka. Mempersiapkan mereka dengan sarana-sarana yang menuju kepada ilmu pengetahuan, kekuatan, sehingga jelas bagi mereka jalan kehidupan yang terhormat dan mulia. Menyadari posisinya kehidupan ini, berwenang memajukan dan mengatur masyarakatnya kelak di tangannya pula terletak kewajiban membebaskan manusia dari kebodohan.

2. menanamkan kesadaran untuk berpikir terhadap adanya hubungan yang erat antara keluarga dengan tanggung jawab sosial, tolong-menolong antar perorangan sesuai dengan ajaran Islam.

3. memperkenalkan kepada murid-murid sistem dan pola hidup muslim dalam bidang pergaulan, seperti menepati janji, teguh pendirian, benar, toleransi, undang-undang perkawinan dan hak tetangga.

4. membimbing anak didik ke arah yang benar dan mampu menolong mereka untuk berinteraksi sosial yang utuh dan pergaulan yang harmonis sesama anggota masyarakat.

5. menguatkan rasa kesadaran nasionalisme yang dimanifestasikan dalam kecintaan kepada tanah air, melindungi, kesediaan berkorban karena tanah air, melindungi dan ikut memelihara kemerdekaan dengan keyakinan bahwa itu semua termasuk prinsip ajaran agama.

6. meyakinkan mereka bahwa agama Islam adalah kemerdekaan, persaudaraan dan keselamatan antar manusia yang beraneka kepercayaan, warna kulit dan tanah air.

7. mengajar anak didik untuk memahami Islam sebagaimana pemahaman para pemuka utama dari sahabat Nabi, yang mampu menyingkap tabir dari

${ }^{15}$ Muhammad Abdul Qadir Ahmad, Thuruqu Ta'limi Al-Tarbiyah Al-Islamiyah: Metodologi Pengajaran Pendidikan Agama Islam, (Jakarta: Direktorat Jenderal Pembinaan Kelembagaan Agama Islam, 1985), h. 164-165

${ }^{16}$ Muhammad Abdul Qadir Ahmad, Thuruqu Ta'limi Al-Tarbiyah Al-Islamiyah: Metodologi Pengajaran Pendidikan Agama Islam, (Jakarta: Direktorat Jenderal Pembinaan Kelembagaan Agama Islam, 1985), h. 204 
khazanah Agama. Prinsip-prinsip kemanusiaan, pandangan hidup,dan kedudukan manusia didalamnya. ${ }^{17}$

Menurut Abdul Qadir Ahmad bahwa "Pada pembelajaran sejarah kebudayaan Islam umumnya merenungkan dan mempikirkan tentang kejadian-kejadian dan peristiwa-peristiwa yang terjadi dalam kisah-kisah masa lalu.,"18

Dalam Jurnal pendidikan Islam bahwa:

Kisah-kisah Qur'ani dan kisah-kisah para nabi itu ialah:

1. dapat memantapkan semangat juang serta menenangkan hati

2. dapat memetik pelajaran-pelajaran kebenaran yang terkandung di dalam kisah

3. dapat mengambil petunjuk-petunjuk dan nasihat-nasihat yang baik

4. Dapat dijadikan peringatan yang berharga bagi orang-orang yang beriman ${ }^{19}$

Pada esempatan ayat yang lain, Allah Swt. secara tegas juga memerintahkan kepada setiap manusia yang berakal tinggi untuk mengambil i'tibar dari kejadian-kejadian dan peristiwa-peristiwa yang ada.

Dengan jalan mengambil i'tibar, jelas akan membawa dampak positif bagi kelangsungan pendidikan dan pengajaran peserta didik. Oleh karena itu, seorang pendidik atau guru muslim hendaknya pandai-pandai untuk mencari kisah-kisah yang dapat diambil i'tibar untuk peserta didiknya.

Menurut Mangun Budiyanto bahwa:

Pelajaran Sejarah kebudayaan Islam dapat dipadukan dengan metode-metode lain sesuai dengan materi yang hendak diajarkan. Di antara metode-metode yang dapat dipadukan tersebut adalah:

1. At-Thariqatu bil mau'idhah

2. At-Thariqatu bil kalami as-şarih

3. At-Thariqatu bil qudwati as-şâlihah

4. At-Thariqatu bil 'ibrah wa bil qisshah. ${ }^{20}$

Para tokoh pendidikan tidak memungkiri pengaruh kisah pada jiwa pendengarnya. Kisah/cerita berkembang seiring dengan lahirnya manusia dan mengikuti perkembangannya, meskipun berbeda masa. Metode kisah termasuk salah satu metode yang sukses dan berhasil. Dalam pendidikan Islam metode Kisah telah dipergunakan sejak munculnya Islam itu sendiri. Hal ini terbukti, Al-Qur'an dalam usahanya mendidik umat manusia banyak menggunakan jalan mengungkapkan kisah-kisah yang mengandung suri teladan yang baik. Dari keseluruhan ayat al-Qur'an yang berjumlah

\footnotetext{
${ }^{17}$ Muhammad Abdul Qadir Ahmad, Thuruqu Ta'limi Al-Tarbiyah Al-Islamiyah: Metodologi Pengajaran Pendidikan Agama Islam, (Jakarta: Direktorat Jenderal Pembinaan Kelembagaan Agama Islam, 1985), h. 206

${ }^{18}$ Mangun Budiyanto, Ilmu Pendidikan Islam, (Yogyakarta, Griya Santri, 2010), h. 156-157

${ }^{19}$ Jurnal Pendidikan Islam : Volume I, Nomor 1, Juni 2012/1433

${ }^{20}$ Mangun Budiyanto, Ilmu Pendidikan Islam, (Yogyakarta, Griya Santri, 2010), hlm 159.
} 
kurang lebih 6.666 ayat ada lebih dari 1600 ayat mengenai kisah-kisah. ${ }^{21}$ Bahkan, Islam menyadari sifat alamiah manusia untuk menyenangi kisah, dan menyadari pengaruhnya yang besar terhadap hati dan jiwa. Kisah juga dapat memberikan stimulasi kepada peserta didik dan secara otomatis mendorong peserta didik untuk berbuat kebajikan serta dapat membentuk akhlak mulia. ${ }^{22}$ Oleh karena itu, pendidikan Islam mengeksploitasi kisah/cerita itu untuk dijadikan salah satu metode atau teknik dalam pendidikan dan pengajaran. ${ }^{23}$

Adapun tujuan dalam pelajaran Sejarah Kebudayaan Islam diantaranya: Pertama, memahami dan mengambil ibrah sejarah dakwah Nabi Muhammad pada periode Makkah dan periode Madinah, masalah kepemimpinan umat setelah Rasulullah SAW wafat, perkembangan Islam pada abad klasik/zaman keemasan (650 - $1250 \mathrm{M})$, abad pertengahan /zaman kemunduran (1250 M - $1800 \mathrm{M})$, masa modern/zaman kebangkitan (1800-sekarang), serta perkembangan Islam di Indonesia dan di dunia. Kedua, mengapresiasi fakta dan makna peristiwa-peristiwa bersejarah dan mengaitkannya dengan fenomena kehidupan sosial, budaya, politik, ekonomi, iptek dan seni. Ketiga, meneladani tokoh-tokoh Islam yang berprestasi dalam perkembangan sejarah kebudayaan/peradaban Islam. ${ }^{24}$

Metode mengajar sejarah dimulai dengan appersepsi ${ }^{25}$ dengan menanyakan keadaan siswa yang diiringi dengan pertanyaan seputar materi yang akan diajarkan. Hal ini dilakukan untuk membangun kognitif siswa terhadap pengetahuan baru yang akan ditambahkan, sehingga guru dapat memetakan pengetahuan siswa terhadap materi atau pengetahuan baru yang akan disampaikan.

Gaya bahasa yang menarik perhatian perlu dilakukan agar perhatian siswa tertuju kepada guru. Dalam menyampaikan sejarah metode CTL merupakan metode yang ideal dalam menyampaikan pesan menuju pemahaman.

Metode belajar perlu dipahami guru agar dapat melaksanakan pembelajaran secara efektif dalam meningkatkan hasil belajar atau kompetensi yang diharapkan.

Setelah appersepsi seorang guru memberikan penjelasan materi secara umum yang berkenaan dengan perkembangan Islam pada periode klasik periode klasik (zaman keemasan) pada tahun $650 \mathrm{M}-1250 \mathrm{M}$. Setelah pemaparan selesai, dilanjutkan dengan pencarian dan mengidentifikasi peristiwa-peristiwa penting dan tokoh-tokoh yang berprestasi dalam perkembangan Islam pada periode klasik.

${ }^{21}$ A. Hanafi, Segi-segi Kesusastraan pada Kisah-kisah Al-qur'an, (Jakarta: Pustaka Al-Husna, 1984), h. 22

${ }^{22}$ Abdul Mujib dan Jusuf Mudzakir, Ilmu Pendidikan Islam, (Jakarta: Kencana Prenada Media Group, 2006), h. 193

${ }^{23}$ Muhammad Quthb, Sistem Pendidikan Islam, Pent. Salman Harun, (Bandung: PT. Alma'arif, 1993), h. 382

${ }^{24}$ Peraturan Menteri Agama Nomor 8 Tahun 2008 tentang Standar Kompetensi Lulusan dan Standar Isi Pendidikan agama Islam dan Bahasa Arab di Madrasah.

${ }^{25}$ Dalam appersepsi guru lebih menugaskan siswa membaca judul tersebut yang terdapat dalam buku At-Tarbiyah Al-Islamiyah sebelum dipelajari dalam kelas. Pertanyaan appersepsi diantaranya dengan memakai pertanyaan mengapa, siapakah, bagaimana dan dimana. Lihat: Muhammad Abdul Qadir Ahmad, Thuruqu Ta'limi Al-Tarbiyah Al-Islamiyah: Metodologi Pengajaran Pendidikan Agama Islam, (Jakarta: Direktorat Jenderal Pembinaan Kelembagaan Agama Islam, 1985), h. 169 
Hal ini merupakan proses dari inkuiri yang dilakukan oleh masing-masing siswa denga harapan pencarian tersebut merupakan salah satu proses pembelajaran yang bermakna sehingga hasil temuan itu menjadi pengetahuan tambahan dan siswa merasa yakin akan temuannya tersebut yang masuk kedalam struktur kognitifnya.

Selanjutnya siswa dibagi menjadi beberapa kelompok untuk mendiskusikan makna yang dapat diambil (ibrah) dari perkembangan Islam pada periode klasik untuk kepentingan masa kini dan yang akan datang. Untuk memantapkan sebuah metode pembelajaran yang bermakna siswa dapat memberikan gambaran melalui diskusinya. Dengan meneladani para tokoh-tokoh yang berprestasi dalam perkembangan Islam. Melalui konsep tersebut siswa dapat meneladaninya sebagai proses dari pembelajaran yang bermakna dan menjadi uswatun hasanah bagi dirinya sendiri.

Pada tahapan ini sebenarnya metode CTL memiliki makna yang bersifat abstrak, namun pembelajaran bermakna akan tercipta apabila struktur kognitif siswa dapat dikaitkan dengan pengetahuan baru.

Sejarah pada intinya memberikan kabar tentang peristiwa-peristiwa di masa lampau, walaupun tidak dialami oleh siswa, paling tidak dapat dijadikan sebagai ibrah, karena bagaimanapun juga sejarah merupakan cerminan bagi siswa untuk melangkah maju dan meneladani figur yang terdapat di kala itu.

Setelah pengetahuan dikonstruksikan, murid dan guru memulai dengan bertanya kepada siswa berkenaan dengan masa keemasan Islam dan siapa saja yang terlibat didalamnya sehingga siswa memahami tentang apa yang harus dilakukan agar informasi melalui proses tanya jawab berhasil dengan baik.

Pembelajaran dilanjutkan dengan mencari informasi yang menceritakan tentang sejarah atau latar belakang Islam mengalami kejayaan dan mengidentifikasi faktorfaktor yang menyebabkan kemajuan Islam pada saat itu.

Setelah siswa mencari dan menemukan sendiri, guru menyiapkan beberapa pertanyaan yang dapat didiskusikan melalui kerja kelompok, hal ini terdapat kelebihan karena siswa dipandang mampu semuanya karena belajar bersama antara teman yang satu dengan yang lainnya dan ini bersifat bebas bagi setiap kelompok.

Kemudian siswa membawa hasil identifikasinya kepada guru untuk dijadikan sebagai metode pembelajaran. Hal ini merupakan hal yang baik, kaena siswa dapat menunjukan hasil karyanya kepada teman dan guru untyuk dijadikan metode pembelajaran.

Selama kegiatan berlangsung, guru menilai siswa dengan penilaian nyata. Penilaian nyata dilihat dari hasil kerja kelompok, keaktifan selama proses pembelajaran berlangsung. 


\section{Simpulan}

Implementasi pembelajaran konstektual pada mata pelajaran agama Islam dengan cara mengkonstruksikan pengetahuan siswa terhadap materi yang akan disampaikan. Siswa dapat menemukan informasi baru melalui curah pendapat dan mencari tambahan materi yang sedang dipelajari melalui internet atau media cetak. Siswa dapat bekerjasama antar kelompok untuk mendiskusikan materi yang sedang dipelajari. Siswa memberikan komentar terhadap model yang ditampilkan pada masingmasing kelompok. Proses tersebut dinilai sebagai penilaian nyata yang dilihat dari keaktifan, tingkah laku siswa ketika mengemukakan gagasan atau menolak pendapat. Selanjutnya siswa merenungkan proses pembeajaran yang telah dialami untuk dijadikan sebuah proses yang dapat bermakna bagi kehidupan.[]

\section{Daftar Pustaka}

Abdul Mujib dan Jusuf Mudzakir, Ilmu Pendidikan Islam, Jakarta: Kencana Prenada Media Group, 2006.

Ahmad, Muhammad Abdul Qadir. Thuruqu Ta'limi Al-Tarbiyah Al-Islamiyah: Metodologi Pengajaran Pendidikan Agama Islam, Jakarta: Direktorat Jenderal Pembinaan Kelembagaan Agama Islam, 1985.

Azra, Azyumardi. Pendidikan Islam, Tradisi dan modernisasi Menuju Milennium baru, Jakarta : Logos Wacana Ilmu, 1999.

Budiyanto, Mangun. Ilmu Pendidikan Islam, Yogyakarta, Griya Santri, 2010.

Hanafi, A. Segi-segi Kesusastraan pada Kisah-kisah Al-qur'an, Jakarta: Pustaka AlHusna, 1984.

Jabali, Fuad. International Workshop: Teaching Methodology and Capacity Building For Teachers of Islamic Subject in High Schools in High Propinces, PPIM UIN Syarif Hidayatullah Tanggal 12 Agustus 2012.

Jamaludin, "Manajemen Berbasis Sekolah di Indonesia", Tesis, Jakarta: UIN Syahid Jakarta, 2007.

Nata, Abuddin. Studi Islam Komprehensif, Jakarta: Kencana, 2011.

Peraturan Menteri Agama Nomor 8 Tahun 2008 tentang Standar Kompetensi Lulusan dan Standar Isi Pendidikan agama Islam dan Bahasa Arab di Madrasah.

Quthb, Muhammad. Sistem Pendidikan Islam, Pent. Salman Harun, Bandung: PT. Alma'arif, 1993.

Shaleh, Abdul Rachman. Madrasah Dan Pendidikan Anak Bangsa: Visi, Misi dan Aksi, Jakarta: PT Raja Grafindo Persada, 2004.

Yunus, Firdaus M. Pendidikan Berbasis Realitas Sosial-Paulo Freire dan YB. Mangunwijaya, Yogyakarta: Logung Pustaka, 2005. 